Article

\title{
The 'Stifling' of New Climate Politics in Ireland
}

\author{
Louise Michelle Fitzgerald ${ }^{1}$, Paul Tobin ${ }^{2, *}$, Charlotte Burns ${ }^{3}$ and Peter Eckersley ${ }^{4,5}$ \\ ${ }^{1}$ Geography Department, Trinity College Dublin, Dublin 2, Ireland; E-Mail: Ifitzge1@tcd.ie \\ ${ }^{2}$ School of Social Sciences, University of Manchester, Manchester, M13 9PL, UK; E-Mail: paul.tobin@manchester.ac.uk \\ ${ }^{3}$ Department of Politics and International Relations, University of Sheffield, Sheffield, S10 2TU, UK; \\ E-Mail: charlotte.burns@sheffield.ac.uk \\ ${ }^{4}$ Nottingham Business School, Nottingham Trent University, Nottingham, NG1 4BU, UK; E-Mail: peter.eckersley@ntu.ac.uk \\ ${ }^{5}$ Department for Institutional Change and Regional Public Goods, Leibniz Institute for Research on Society and Space, \\ 15537 Erkner, Germany
}

* Corresponding author

Submitted: 30 October 2020 | Accepted: 19 March 2021 | Published: 28 April 2021

\begin{abstract}
In 2019, Ireland declared a 'Climate Emergency,' receiving plaudits from across the political spectrum for doing so. Some argued the country was experiencing an era of 'new climate politics': In 2017, Ireland had established the first Citizens' Assembly on Climate, and in 2019 its Parliament debated a Climate Emergency Measures Bill, which was ground-breaking in its proposal to ban offshore oil and gas exploration. Yet, despite majority support for this Bill in Parliament, the minority Government blocked the legislation by refusing to grant a 'Money Message,' a potential veto activated following indication by an independent actor that a Bill would require the appropriation of public money. We introduce the concept of 'policy stifling' to capture how the Money Message was used to block the Climate Emergency Measures Bill. We conduct detailed process-tracing analysis, building on elite semi-structured interviews with policy makers and campaigners involved in the process. We argue that whilst the Government's stifling undermined the new era of elite climate politics, it simultaneously boosted an emerging grassroots climate politics movement with the potential for effecting more radical change in the longer term.
\end{abstract}

\section{Keywords}

climate change; climate emergency; depoliticisation; Ireland; policy dismantling; policy stifling; public policy; veto theory

\section{Issue}

This article is part of the issue "Is There a New Climate Politics? Emergency, Engagement and Justice" edited by Anna R. Davies (Trinity College Dublin, Ireland), Stephan Hügel (Trinity College Dublin, Ireland) and Vanesa Castán Broto (University of Sheffield, UK).

(C) 2021 by the authors; licensee Cogitatio (Lisbon, Portugal). This article is licensed under a Creative Commons Attribution 4.0 International License (CC BY).

\section{Introduction}

Ireland has the reputation of being a climate laggard (e.g., Little \& Torney, 2017). Yet recent developments-such as the Citizens' Assemblies in 2017-2018 that discussed how Ireland can become a climate leader, the adoption of a Climate Action Plan in 2019 (Torney, 2020) and declaration of a climate emergency on the 9th May 2019seemed to suggest a turning of the tide on climate action during the minority government of 2016 to 2020. This period also witnessed a growing climate movement in
Ireland, which along with some legislative progress on climate change, seemed to show that a new era of climate politics had arrived. However, whilst there have been steps forward, close analysis of technical legislative processes that led to the rejection of the Climate Emergency Measures (CEM) Bill reveals that the claim of a new era of elite climate politics may be premature, with climate action falling short of the transformations needed. The familiar trade-offs between short-term economic interests and environmental ambition that have long characterised climate politics in Ireland remain in 
place. In this article, we present evidence of pressure being applied to an independent actor to facilitate the vetoing of policy proposals that could advance the climate agenda, through the use of the Money Message, which we describe in more detail below. We develop a novel concept of 'policy stifling' to describe this type of behaviour and suggest that decision-makers who engage in policy stifling seek to depoliticise their actions, in order to minimise wider political costs.

The next section outlines the operation of the Irish political process and the nature and status of the Money Message, before we develop and explain the concept of 'policy stifling,' drawing from the literature on veto points, policy dismantling and depoliticisation. We then outline our process-tracing methodology, and data collection for the period under investigation (2016-2020). Fourth, we analyse how Ireland's minority government fluctuated in its policy positions towards the climate emergency. Finally, we discuss our empirical findings and offer some conclusions.

\section{The Irish Political System and the 'Money Message'}

In Ireland, the Government, as the institution responsible for the country's economy and for proposing an annual budget, would be placed in a challenging position if it had no executive control to limit Bills with economic implications. Thus, Article 17.2 of the Constitution of Ireland states that the Dáil (parliamentary lower house) may not pass or enact a law "for the appropriation of revenue or other public moneys unless the purpose of the appropriation shall have been recommended to Dáil Éireann by a message from the Government signed by the Taoiseach [Prime Minister of Ireland]" (Constitution of Ireland, 2018). This message, signed by the Taoiseach, is what has become known as a Money Message, and is a traditional formal veto (see Kenny \& Daly, 2019). The government is entitled to exercise this veto if the legislation is deemed to appropriate revenue or other public moneys.

To become law, all Bills must pass through five stages in each of the two legislative chambers: the Dáil and the Seanad. If and when a Bill secures a majority at the Second Stage of the five in the Dáil, the Ceann Comhairle (Speaker of the Dáil), advised by the independent parliamentary Bills Office, determines if a Money Message is required. As in many legislatures, the Ceann Comhairle is an elected parliamentarian who is expected to "preside impartially" in the chamber (Houses of the Oireachtas, n.d.). In May 2019, the Oireachtas Library and Research Service published a Note on Private Members' Bills (PMBs; Lynch \& Lawlor, 2019), which listed 55 PMBs within the 32nd Dáil that were deemed to require a Money Message after reaching the Third Stage (in Select Committee), having already secured a majority in the Dáil. A further 14 PMBs did not require a Money Message.

Traditionally, Irish governments have benefited from parliamentary majorities, and therefore have not nor- mally vetoed legislation by refusing to grant a Money Message if one is required, because any Bill that reaches this stage would already have the support of ministers. In cases where legislation is initiated by backbench parliamentarians (Teachtaí Dála, henceforth TDs), and the Bills Office and the Ceann Comhairle judge that a Money Message is necessary, the government can use this procedure to block legislation-although it does not always choose to do so. For example, in the case of the National Famine Commemoration Day Bill 2017, proposed as a PMB by Colm Brophy TD of the governing Fine Gael party, a Money Message was granted in May 2018 (Houses of the Oireachtas, 2019b). In contrast, a Money Message for the Waste Reduction Bill 2017, proposed by Green Party TDs Eamon Ryan and Catherine Martin, was not granted.

Our contention in this article is that the Irish Government persuaded the supposedly independent Ceann Comhairle that a potentially transformative CEM Bill required a Money Message, thereby reversing a previous decision that this was unnecessary. This enabled ministers to 'stifle' the proposed legislation. In the following section, we outline our concept of policy stifling, before explaining our case selection in more detail in Section 4.

\section{Policy Stifling}

It is generally accepted in legislative studies that legislation can be blocked during the agenda-setting stage, whilst being discussed, or after being agreed. We review each of these approaches, before proposing our own concept of 'policy stifling.'

First, policymakers may obstruct proposals before they are even formally discussed, or voted upon, through 'non-decision-making.' Bachrach and Baratz (1962) labelled this behaviour the 'second face of power': the ability of elites to set the agenda and thereby avoid debating and taking an active decision in the first place. Such behaviour can ensure that elites avoid paying the political price for opposing legislation that would have garnered popular support, as they do not need to reveal their opposition publicly. Second, policymakers can actively block policy proposals using formal veto powers granted to them in the legislative process (Tsebelis, 1995). In order to do so, however, a proposal must be submitted formally, in contrast to the principle underpinning pre-emptive non-decision-making. Finally, policy dismantling is the "cutting, diminution or removal of existing policy" (Jordan, Bauer, \& Green-Pedersen, 2013, p. 795), which typically applies to legislation that has been adopted.

Whilst at first glance these approaches cover the main stages of the policy cycle (proposal, adoption and implementation), they overlook an important subset of policies that have been proposed and received support from the legislature but have yet to become law. During this window, governments wishing to obstruct a Bill's passage may seek to create new veto points in a way that means they are not punished by the electorate 
for potentially unpopular decisions. Such a scenario has been neglected in the existing literature.

We propose that this behaviour is best captured by our proposed concept of 'policy stifling': the creation of a new veto point via government lobbying of an independent actor. Such stifling occurs once a Bill has already received majority support within the lower house. Moreover, we suggest that stifling is more likely when an independent actor plays a critical role in the policy adoption process, which is consistent with wider studies on depoliticisation, namely "the process of placing at one remove [i.e., with a degree of separation] the political character of decision-making" (Burnham, 2001, p. 128). The phenomenon is often pursued by establishing arms-length bodies and procedural mechanisms that give independent actors (which are sometimes 'neutral,' and sometimes unelected) greater influence over public functions (see Flinders \& Buller, 2006). Sometimes viewed as a way to improve the legitimacy of policymaking, depoliticisation as a governing strategy has attracted much normative criticism on the basis that it deflects blame and reduces democratic oversight and accountability (Flinders \& Wood, 2015). Subsequently, others argued that focusing solely on the exercise of state functions limits our understanding of what is 'political' (Beveridge, 2017) and both the narrow and broader understandings have relevance for environmental policymaking.

This framework is clearly relevant for analysing the era of climate politics. Key dimensions of climate policy, such as energy and planning, are broadly technocratic, as engineers, economists and bureaucrats tend to dominate policy design and implementation (Healy \& Barry, 2017), and expert bodies often play important roles in decision-making. As Hajer (1995) notes, the politics of environmental change have become narrowly focused on such technical and administrative matters, squeezing out broader political contestations (Mangat, Dalby, \& Paterson, 2018). However, as Healy and Barry (2017) note, climate politics more broadly are "not simply a technological or indeed a socio-technical matter" but rather inherently contested, "characterised by issues of power, distribution of and access to resources, political economy, and so on, it can be described as a deeply political struggle" (Healy \& Barry, 2017, p. 452).

Our concept of policy stifling can contribute to wider analyses of public policy and of how governments treat policies that may command broad appeal, but which policymakers are nonetheless reluctant to introduce. Policy stifling is distinct from non-decision-making, vetoing and policy dismantling. First, a policy must be proposed in order to be stifled so does not qualify as non-decisionmaking. Second, a veto is typically defined as the exercise of a formal executive power to reject a proposal at a clearly indicated stage in the legislative process. In policy stifling, the government does not (yet) possess a formal veto, and it therefore lobbies actors to create one. Policy dismantling also differs from stifling, because it refers to the weakening or removal of legislation that has already been implemented. To summarise, we suggest that policy stifling is a distinct political phenomenon that occurs when a government successfully lobbies an independent actor to create a new formal veto point, which the government then employs to block a policy proposal. We now turn to explain our choice of case study method and the case itself, the Irish CEM Bill.

\section{Methods, Data, and Case Selection and Description}

\subsection{Methods and Data}

This article employs a qualitative, process-tracing approach. Process tracing is a "research method for tracing causal mechanisms using detailed, within-case empirical analysis of how a causal mechanism operated in real-world cases" (Beach \& Brun Pedersen, 2019, p. $1)$. In this article, we analyse critically the case of the CEM Bill, and how it came to be vetoed despite securing a majority in the Dáil. Process tracing is used to explain change within cases, and so our case section is structured chronologically, before examining key themes in the discussion. While process tracing the CEM Bill is our primary focus, we also trace the development of other climate policies during 2016-2020, to enable us to reflect upon the development of an era of 'new climate politics' in the discussion, and to review the extent to which the government was willing to act on climate change in other areas. To conduct our analysis, we examined policy documents, legislation, speeches and newspaper articles from the period. We also held eight semi-structured elite interviews with relevant figures in October 2019 and in May 2020 (see Table 1; referenced as INT1 to INT8). The interviewees included an Irish MEP's assistant, an Irish environmental campaigner, two Irish civil servants, three environmental NGO volunteers, a Government Minister, a parliamentary assistant, and a journalist. The interviews were each recorded and then transcribed in full, before being coded using an iterative, inductive codebook. This coding process identified 23 themes that were discussed during the interviews, not all of which were directly relevant to our investigation.

\subsection{Case Selection and Description}

We selected the Republic of Ireland as a case due to its Janus-faced policy stances on 'climate emergency' legislation. The existing literature on Irish environmental policy focuses on Ireland's status as a laggard (Little \& Torney, 2017) and notes how vigorous lobbying by business and farming groups hindered the development of more ambitious climate policy between 2007-2016 (Torney, 2017; Torney \& O'Gorman, 2019). To date, there has been limited academic examination of climate governance under the minority 2016-2020 government or the development of 'new climate politics' in response to widespread efforts to address the climate 
Table 1. Interview list.

\begin{tabular}{lll}
\hline Code & Date & Interviewee \\
\hline INT1 & $23 / 10 / 2019$ & Irish MEP's assistant \\
INT2 & $24 / 10 / 2019$ & Irish environmental campaigner \\
INT3 & $24 / 10 / 2019$ & Irish civil servant \\
INT4 & $29 / 10 / 2019$ & Three Environmental NGO volunteers \\
INT5 & $29 / 10 / 2019$ & Irish civil servant \\
INT6 & $25 / 10 / 2019$ & Government Minister \\
INT7 & $06 / 05 / 2020$ & Parliamentary assistant \\
INT8 & $06 / 05 / 2020$ & Journalist \\
\hline
\end{tabular}

emergency. Lijphart (1999) placed Ireland between a majoritarian and consensual democracy in his classification, but the Republic has become more consensual over time, with the number of one-party cabinets falling over the decades (Bulsara \& Kissane, 2009). Ireland's Single Transferable Vote electoral system has resulted in an increasingly wide range of parties within the Dáil.

The period under investigation ran from 26th February 2016 to 8th February 2020, covering the full term of Ireland's minority government, in which the lowest ever number of seats were returned for traditional parties, and includes the rise of the 'climate emergency' movement and Fridays for Future strike campaign. In 2016, an electoral swing away from the traditionally dominant two main parties resulted in a coalition government of the centre-right Fine Gael party with Independent TDs, relying on 'confidence and supply' support from the other traditionally dominant party, Fianna Fáil. This period clearly had the potential to herald a 'new politics' in which non-government TDs could exercise much greater legislative influence than previously, and governance innovations such as Citizens' Assemblies provided new platforms for political debate (Devaney, Torney, Brereton, \& Coleman, 2020). This 'new politics' has become more apparent since 2011, and has been defined to date by growing levels of support for Sinn Fein, as well as for independent candidates and other, mainly left-of-centre, smaller parties, that focused specifically on green issues (Kavanagh, 2015, p. 79). Overall, there was a narrative of change and breaking new ground for democracy in Ireland: "The dawn of this [2016-2020] Dáil was heralded by talk of reform. Opposition TDs would be listened to. Their ideas would make it into legislation. And those laws would be passed by compromise" (Doyle, 2018).

Finally, for greater understanding of the role of bottom-up movements in agitating for political change, Ireland is an interesting context to study. Comparatively, Irish citizens have one of the highest levels of access to politicians, due to Ireland's relatively small size, the path dependent practices of contact and interaction with politicians such as a tradition of 'weekly clinics,' and a voting system that incentivises politicians to be generally responsive to those in their constituencies. Indeed, in $2016,15.8 \%$ of citizens were found to have contacted their TDs in the preceding year period, whilst $87 \%$ of those were contacted during the 2016 election campaign (Farrell, Gallagher, \& Barrett, 2018, p. 198). The particularities of the Irish system, including its Proportional Representation Single Transferable Vote system, have been suggested to encourage clientelism, which is seen as a hurdle to progress as it leads politicians to focus on their own constituencies rather than national issues (see Gallagher, 2019). However, the responsiveness of Irish politicians to their constituents should mean that if a desire for action on the climate emerges within the electorate, this can be communicated to political representatives relatively easily and could result in more ambitious climate policy. So, in this context, the country exhibits two factors that could facilitate progress in climate policy: a short chain of contact between politicians and citizens (including climate movements), and the emergence of a 'new politics' due to a minority government, dynamic party constellations and governance innovations. Given these favourable conditions, examining Ireland offers insights into the scope and emergence of a new climate politics to date, and potential lessons for the future.

\section{Case Study: Stifling the Climate Emergency Measures Bill}

In 2017, Ireland held its first Citizens' Assembly on how to make the country a global leader on climate action (Devaney et al., 2020), following the successes of Citizens' Assemblies in addressing other contested issues (INT5). One outcome of the Citizens' Assembly was the formation of a new parliamentary committee, the 'Joint Oireachtas ('legislature') Committee on Climate Action,' (known as JOCCA) comprising TDs from six parties plus two Independent TDs, to consider the citizens' recommendations. Eight days after the UK parliament's declaration of a climate emergency on 1st May 2019, Ireland followed suit. The declaration came via 
an eight-word amendment moved by the Green Party, added to a motion endorsing a JOCCA report already passing through the Oireachtas. With only six of 160 TDs present in the House when the declaration was debated and passed, Green Party leader Eamon Ryan acknowledged its potentially limited and purely symbolic nature, stating that "declaring an emergency means absolutely nothing unless there is action to back it up" (Climate Emergency Declaration, n.d.). The declaration did not contain substantive provisions or information about how it would be implemented or enforced, and lacked the necessary resources needed for it to make a significant structural change.

Crucially, at the same time as the declaration, another proposal, the CEM Bill, was passing through the parliament. This Bill did contain specific provisions that could deliver meaningful climate mitigation, as it explicitly prohibited the government from granting new fossil fuel extraction licences. Notably, according to one of our interviewees (INT2), the Bill was pursued because of the 'new politics' context: "We live in this magical time of having a minority government, so you can still pass legislation when you are in the opposition....So this is a tremendously exciting thing for our campaign group."

Bríd Smith TD, of the Solidarity-People Before Profit party, introduced the CEM Bill on the 15th November 2017. The Bill was an amendment to the Petroleum and Other Minerals Development Bill, stating that, "while the climate emergency still exists, no new licenses shall be issued from this country for oil and gas," thus containing policy proposals that would address the problem in question and could be enforced relatively easily. On 30th January 2018, a revised and more detailed version of the Bill was introduced to the Dáil. Stop Climate Chaos, a coalition of over 30 civil society organisations, mobilised around the Bill, designing an email tool for people to contact their TDs directly. Campaigners focused on lobbying non-government TDs in order to take advantage of the minority government context. Fianna Fail, the second largest party in the Dáil, which propped up the Government in a confidence-and-supply arrangement, took a 'landmark position,' coming out in support of the Bill (O'Sullivan, 2018). On the 8th February 2018, with the support of Independent TDs and opposition parties, the Bill was supported by 78 TDs voting in favour at the Second Stage, while 48 voted against (Houses of the Oireachtas, 2018a; Lee, 2018).

In line with standard practice, the politically independent Bills Office reviewed the Bill to determine if it required a Money Message. In this case, as the Bill was judged to have no cost implications nor to need the appropriation of public funds, the Bills Office apparently stated that a Money Message was unnecessary (Crosson, 2019a). Speaking later on the matter, the Chair of the Joint Oireachtas Committee on Communications, Climate Action and Environment, Hildegarde Naughton of the governing Fine Gael party, confirmed this interpretation when she stated:
I have a letter here from the Bills Office dated 26 February 2018, addressed to the then clerk to the committee, to the effect that this Bill does not require a money message, financial resolution or European Central Bank, ECB, consultation. (Houses of the Oireachtas, 2019a)

Thus, by March 2019, the Bill had received majority support in the Dáil on two occasions. The second time it was endorsed in the Dáil was to progress it after a tied vote in the Joint Oireachtas Committee. The tied vote in December 2018 had resulted in a 'procedural cul-de-sac' for the Bill as described by Bríd Smith TD, with the Leader of the Green Party, Eamon Ryan TD, questioning whether it would be "another environmental Bill which Fine Gael have been able to kill with procedural glue" (Sargent, 2018). After a period in 'limbo,' on 28th March 2019, Smith forwarded a motion in the Dáil that would allow the Bill to progress to select committee stage, whilst citizen groups protested outside the Dáil in support of the Bill (Crosson, 2019b). The vote resulted in the Bill being allowed to progress, with Smith including Not Here, Not Anywhere, Stop Climate Chaos, Trocáire (the overseas development agency of the Catholic Church in Ireland), and Friends of the Earth Ireland, in her thanks to those who supported the Bill (Crosson, 2019b). Thus, the Bill had two supportive votes in parliament, had been deemed not to need a Money Message, and was scheduled for Select Committee ('Third') Stage three months later (People Before Profit, 2019a).

Despite earlier progress, in May 2019, Seán Canney TD, Minister for Natural Resources, Community Affairs and Digital Development, wrote a letter to the Ceann Comhairle requesting further consideration of the money message decision (Houses of the Oireachtas, 2019a). He argued that the legislation might open the government up to legal costs, and result in the government losing revenue from fossil fuel drilling licences, and that this money could be used to fund the green transition (Houses of the Oireachtas, 2019a). Despite the Ceann Comhairle and Bills Office being independent of the government, and despite the fact that the usual timing for deciding whether a Money Message was required had passed, the Ceann Comhairle reversed the previous decision and decided that a Money Message was necessary for the Bill. Highlighting the paradox behind declaring a Climate Emergency but opposing a Bill that had climate implications, Deputy Smith (also a member of the Committee on Communications, Climate Action and Environment) asked the government:

What, if anything, does a climate emergency mean if it is not that we have to take cognisance of the level of $\mathrm{CO}_{2}$ in the atmosphere? Does that not constitute the basis of an emergency? We have just declared such an emergency in Dáil Éirean. (Houses of the Oireachtas, 2019a) 
However, the Government did not grant the Money Message. On the 4th July 2019, Minister for Communications, Climate Action and Environment Richard Bruton wrote to Smith to explain why the Government would not grant the Bill a Money Message. Bruton argued that the legislation would not make any contribution to delivering Ireland's carbon reduction targets, but simply necessitate the importation of fossil fuels instead (McCrave, 2019). Furthermore, the Bill was said to ignore "the potential financial implications of the proposal," and listed other targets such as retrofitting 500,000 buildings, which had "been selected based on those choices which are the least cost to society as a whole" (McCrave, 2019). Thus, the government stifled the passage of a Bill that had already obtained majority support in the legislature, by encouraging an independent actor to create a veto point that it could then employ. In the words of our interviewees, "it was just clearly...a last ditched attempt to kill the Bill" (INT8). The interviewee went on to comment on the obscure way in which the Money Message was employed, arguing that "arguments used by the government were dubious at best" (INT8), with another interviewee adding, "they were making the argument that this piece of legislation which simply says 'don't grant any new licenses' impacts the budget. Which I believe is spurious, which is unfair" (INT2).

In response to this policy stifling, on the 5th November 2019, the Solidarity-People Before Profit party sought to propose in the Dáil that the Standing Orders be changed, such that Bills that had been blocked by the government using the Money Message could proceed (Finn, 2019; People Before Profit, 2019b). The party also proposed that the Government could no longer block Bills because of potential incidental expenses or indirect costs (People Before Profit, 2019b). However, the Ceann Comhairle refused to allow the party to use its Private Members' time to do so, citing concerns about its constitutionality (Finn, 2019). Following much parliamentary controversy over the "undemocratic" use of the Money Message (Finn, 2019), several delays, a High Court challenge (McConnell, 2019) and a General Election on the 8th February 2020, the CEM Bill lapsed with the dissolution of the 32nd Dáil and Seanad. Thus, a Bill that had achieved a parliamentary majority was successfully stifled, while the Climate Emergency Declaration remained as a clarion of the urgency of climate change.

It is worth noting, of course, that the CEM Bill was not the only climate measure discussed in the period under study. In June 2019, the Government passed a Climate Action Plan comprising 183 actions, assessed on a quarterly basis. Our interviewees varied in their perceptions of the Plan, from describing it as "really significant. That is the blueprint" (INT3) and "covering every segment of public, enterprise and private life" (INT6), to being "watered down and...discarding the citizens' recommendations" (INT2). Environmental and human rights groups levelled a "devastating critique" of the Plan, with more than 30 of these organisations "describing it as lacking detail, ambition and urgency" (O'Doherty, 2019). The CEM Bill, however, received broad support from environmentalists. Thus, the CEM Bill, and the wider era of supposed 'new politics' during the 32 nd Dáil, is a useful case to analyse in order to establish whether a new climate politics is emerging, bolstered by grassroots calls for wide reaching transformative change.

\section{Discussion}

The 32nd Dáil saw several hallmarks of an era of 'new politics,' through the mobilisation of new coalitions and parliamentary tactics, but also the increased significance of the Money Message, which became a vehicle through which the government could halt the progress of climate politics. The CEM Bill had been passed twice by the Dáil: once following its introduction and again to progress the Bill after a tied vote in the Joint Oireachtas Committee on Communications, Climate Action and Environment. Nevertheless, the Government was able to delay, block and finally stifle its progress, through its encouragement of the Ceann Comhairle to employ the Money Message. Given that political forces were able to act in this way, claims that a new climate politics were emerging in Ireland seemed premature-at least at the elite level.

Our contribution of the concept of policy stifling enables greater analytical leverage in understanding veto theory, and the steps governments may take to block legislation they do not support. Building on the existing literature, we outlined how the Irish government attempted to depoliticise its highly political decision on the CEM Bill, by persuading the independent Ceann Comhairle that the legislation required a Money Message after all. That the Bill would put pressure on the public finances was not abundantly clear, and indeed, the initial decision that it did not need a Money Message makes the final decision that it (a) did require one and (b) would not receive one, all the more puzzling. What is clear, however, is that the government appeared reluctant to ban oil and gas drilling and would therefore be keen to prevent the Bill becoming law. Though understanding ultimate motivations is not possible, the Government did cite several financial reasons for its decision, including loss of revenue from licenses, the risk of legal action (O'Sullivan \& Horgan-Jones, 2019), the availability of less costly approaches via its own Climate Action Plan and the prospect that the monies from fossil fuel extraction could be used to fund the green transition. By framing its decision in such financial terms, we can see how the government was able to argue that the Bill should require a Money Message and therefore enable it to stifle the legislation.

This case provides new insights for the concept of policy stifling. First, previous studies of similar practices focus on official channels for vetoing proposals (Tsebelis, 1995), or dismantling legislation after it has been implemented (Bauer \& Knill, 2012). We introduce the concept 
of policy stifling to this mix by showing how governments can employ mechanisms to depoliticise decisions that undermine legislative proposals and thereby try to reduce the political costs that explicitly blocking legislation could incur. Second, while the usage of the Money Message was low-profile and unfamiliar for much of the 32nd Dáil, its extensive usage over time led to a court case related to seeking to reduce its use. By the time of the case in November 2019, the Money Message had become high-profile, obtaining detailed coverage in national newspapers (Finn, 2019). To be explicit: in minority government contexts, it is the decision of the Ceann Comhairle and recommendation of the Bills Office as to whether a PMB requires a Money Message that determines whether the government can veto a Bill, or is powerless to stop its progression. Stifling bills by lobbying such independent actors may be 'low visibility' at first usage, but employing it frequently is likely to garner more high-profile attention, particularly when applied to salient policy proposals.

Climate emergency declarations could herald an era of new climate politics, with governments acknowledging the severity of the climate crisis and pursuing ambitious action. However, our analysis shows the need to scrutinise parallel policy developments on the ground, lest climate emergency declarations serve as greenwashing that obscures climate action realities. Climate emergency declarations, though increasingly welcomed, do not automatically translate to further action. The aftermath of the Climate Emergency Declaration saw continued and increasing citizen mobilisation around the climate issue, calling for action from government. Indeed, despite stifling the Bill, the Government later moved to ban offshore oil drilling, announced by the then Taoiseach Leo Varadkar at the 2019 UN Climate Action Summit. Further action on climate change may be predicated on the development of anti-fossil fuel norms (Green, 2018), and although the Bill was stifled, subsequent events seem to support the further development of grassroots anti-fossil fuel norms in Ireland during the timeframe analysed. Thus, the new politics may yet establish new norms that galvanise new policy coalitions, which in turn may hold even stronger sway in the event of continued minority government and increasing shifts in Irish electoral behaviour away from the traditional parties. Indeed, shortly before finalising this article in spring 2021, the grand coalition government moved to extend the ban on new offshore drilling to cover gas as well as oil. This new ban was not inevitable, and the citizens' movements agitating for climate action, particularly those seeking to develop anti-fossil fuel norms, such as Not Here, Not Anywhere, have been a key part in such developments. Despite the Government's initial attempt to depoliticise the decision on offshore drilling, therefore, social movements worked to (re)politicise the issue.

Indeed, the role of social movements, and the potential impact of a 'new grassroots climate politics' should not be underestimated. Bríd Smith acknowledged the "tremendous amount of work with Solidarity-People Before Profit in the lead-up to the production and presentation of the Bill" provided by non-governmental organisations (Houses of the Oireachtas, 2018b)-pointing to the role of wider social mobilisation on climate change in the Bill's development. Even though the Bill was stifled by the government, continued mobilisation by citizens solidified its legacy in concrete action. As one interviewee put it: "They killed the Bill, they were coming under huge pressure about that, it wasn't a good look for them, and then [Taoiseach] Varadkar made an announcement over in New York that he was going to ban oil exploration" (INT8). Furthermore, the spread of anti-fossil-fuel norms, which were strengthened by the CEM Bill, provides fertile grounds for new climate politics.

Overall, Ireland witnessed a stifling of the type of climate policy that would constitute a new climate politics approach from government, namely to implement initiatives that would support the radical changes necessary to address the climate emergency. Yet, increasingly active climate movements, and the development of anti-fossilfuel norms through an ambitious policy proposal arising out of and supported by citizen mobilisations, suggest that despite this stifling at government level, a new grassroots climate politics may yet have potential to achieve transformative change.

\section{Conclusion}

Empirically, we found that Ireland's 'new politics,' which seemed to provide the basis for progress on climate issues at the elite level, was stifled by a government that wanted to proceed at a slower pace. The Climate Emergency Declaration did not prevent this stifling and nor did it encourage rapid climate action, which should be a cautionary tale for supporters of more progressive environmental policy. A key factor was the Government's success in lobbying an independent and depoliticised actor to help it block the legislation. However, while the CEM Bill did not pass, its proposals, the Declaration, along with the citizen movements associated with these, may yet have created new norms-alongside new coalitions of actors-for more substantive policies in the future. We would welcome further research into how these fluid politics shape policy across different sectors in Ireland, as well as how the Irish government has employed the Money Message as a veto on other policies not explored here. Indeed, the initial stifling of a ban on offshore oil and gas drilling, followed by the government's decisions to ban oil (and subsequently gas) drilling in the following legislative period, collectively offer a fruitful avenue of research for examining the development of anti-fossil fuel norms and social movements in repoliticising climate issues.

More broadly, we encourage scholars to investigate further the ways in which governments may engage in policy stifling, and which jurisdiction-specific mechanisms and procedures might enable policymakers 
to try to depoliticise potentially unpopular decisions. Depending on the extent to which certain institutions can operate independently of the executive, these could include central banks, government agencies, scientific or advisory bodies, and (in less liberal democratic contexts) the courts. In particular, it would be useful to examine whether and how policy stifling operates in parallel with initiatives (such as climate emergency declarations) in other contexts. Our introduction of the concept of policy stifling captures the behaviour of politicians who wish to be seen to be acting on something, but are unwilling to expend political or financial capital, or perhaps simply do not wish to see meaningful change. Policy stifling is an important new conceptual tool for analysing contexts where (re)politicised action on climate change is increasingly urgent for achieving systemic shifts. Further research should also analyse whether and how policy stifling sits alongside other governmental strategies that aim to weaken or remove existing policies, such as agenda-setting, vetoing and dismantling legislation. Such studies will provide a fuller picture of how policymakers prevent the adoption and implementation of legislation that they oppose.

\section{Acknowledgments}

The authors gratefully acknowledge Conor O'Neill and Dr. Diarmuid Torney's helpful feedback during the development of this article. The authors also thank the three reviewers for their constructive comments. Louise Michelle Fitzgerald is grateful for previous funding received from the Irish Research Council under the Government of Ireland Postgraduate Scholarship, and University College Dublin School of Politics and International Relations (SPIRe) Iseult Honohan Scholarship. Finally, the support of the Economic and Social Research Council (ESRC) is gratefully acknowledged, having funded Paul Tobin via grant ES/S014500/1 during the writing of this article.

\section{Conflict of Interests}

The authors declare no conflict of interests.

\section{References}

Bachrach, P., \& Baratz, M. S. (1962). Two faces of power. The American Political Science Review, 56, 947-952.

Bauer, M. W., \& Knill, C. (2012). Understanding policy dismantling: An analytical framework. In M. W. Bauer (Ed.), Dismantling public policy: Preferences, strategies, and effects (pp. 583-605). Oxford: Oxford University Press.

Beach, D., \& Brun Pedersen, R. (2019). Process-tracing methods. Ann Harbor, MI: University of Michigan Press.

Beveridge, R. (2017). The (ontological) politics in politicisation debates: Three lenses on the decline of the political. Political Studies Review, 15, 589-600.

Bulsara, H., \& Kissane, B. (2009). Arend Lijphart and the transformation of Irish democracy. West European Politics, 32, 172-195.

Burnham, P. (2001). New labour and the politics of depoliticisation. British Journal of Politics and International Relations, 3, 127-149.

Climate Emergency Declaration. (n.d.). Ireland declares a climate emergency. Climate Emergency Declaration. Retrieved from https://climateemergency declaration.org/ireland-declares-a-climateemergency

Constitution of Ireland, 2018.

Crosson, K. (2019a, May 29). Money message an attempt to "sabotage" climate bill, says PBP. Green News. Retrieved from https://greennews.ie/moneymessage-sabotage-bill

Crosson, K. (2019b, March 28). Progress made on climate emergency measures bill. Green News. Retrieved from https://greennews.ie/progress-made-onclimate-emergency-measures-bill

Devaney, L., Torney, D., Brereton, P., \& Coleman, M. (2020). Ireland's citizens' assembly on climate change: Lessons for deliberative public engagement and communication. Environmental Communication, 14, 141-146.

Doyle, K. (2018, May 8). New politics is not perfect but, it has helped steady the ship for two years. The Irish Independent. Retrieved from https://www. independent.ie/irish-news/politics/new-politics-isnot-perfect-but-it-has-helped-steady-the-ship-fortwo-years-36883916.html

Farrell, D. M., Gallagher, M., \& Barrett, D. (2018). What do Irish voters want from and think of their politicians? In M. Marsh, D. M. Farrell, \& T. Reidy (Eds.), The post-crisis Irish voter: Voting behaviour in the Irish 2016 general election (pp. 190-208). Manchester: Manchester University Press.

Finn, C. (2019, November 5). Dáil suspended after argument breaks over 'undemocratic' money message veto. TheJournal.ie. Retrieved from https:// www.thejournal.ie/money-message-bills-blockeddail-4879157-Nov2019

Flinders, M., \& Buller, J. (2006). Depoliticisation: Principles, tactics and tools. British Politics, 1, 293-318.

Flinders, M., \& Wood, M. (2015). When politics fails: Hyper-democracy and hyper-depoliticization. New Political Science, 37, 363-381.

Gallagher, M. (2019). Ireland's PR-STV electoral system: A need for reform? Trinity College Dublin. Retrieved from https://www.tcd.ie/Political_Science/people/ michael_gallagher/IrishElectSys.php

Green, F. (2018). Anti-fossil fuel norms. Climatic Change, $150,103-116$.

Hajer, M. (1995). The politics of environmental discourse: Ecological modernization and the polity process. Oxford: Clarendon.

Healy, N., \& Barry, J. (2017). Politicizing energy justice 
and energy system transitions: Fossil fuel divestment and a "just transition." Energy Policy, 108, 451-459.

Houses of the Oireachtas. (n.d.). Ceann Comhairle. Houses of the Oireachtas. Retrieved from https:// www.oireachtas.ie/en/members/office-

holders/ceann-comhairle

Houses of the Oireachtas. (2018a). Dáil Éireann debateThursday, 8 Feb 2018. Houses of the Oireachtas. Retrieved from https://www.oireachtas.ie/en/ debates/debate/dail/2018-02-08/37/

Houses of the Oireachtas. (2018b). Dáil Éireann debateWednesday, 7 Feb 2018. Houses of the Oireachtas. Retrieved from https://www.oireachtas.ie/en/ debates/debate/dail/2018-02-07/32

Houses of the Oireachtas. (2019a). Joint Committee on Communications, Climate Action and Environment debate-Tuesday, 11 Jun 2019. Houses of the Oireachtas. Retrieved from https://www. oireachtas.ie/en/debates/debate/joint_committee_ on_communications_climate_action_and_ environment/2019-06-11/2

Houses of the Oireachtas. (2019b). Joint Committee on Culture, Heritage and the Gaeltacht report on the detailed scrutiny of the National Famine Commemoration Day Bill 2017 [PMB]. Dublin: Irish Government. Retrieved from https://data.oireachtas.ie/ie/ oireachtas/committee/dail/32/joint_committee_ on_culture_heritage_and_the_gaeltacht/reports/ 2019/2019-05-15_report-on-on-the-detailedscrutiny-of-the-national-famine-commemorationday-bill-2017_en.pdf

Jordan, A., Bauer, M. W., \& Green-Pedersen, C. (2013). Policy dismantling. Journal of European Public Policy, 20, 795-805.

Kavanagh, A. P. (2015). An end to 'civil war politics'? The radically reshaped political landscape of post-crash Ireland. Electoral Studies, 38, 71-81.

Kenny, D., \& Daly, E. (2019). Opinion on the Constitutional limits of the 'money message' procedure under Article 17.2 of the Constitution of Ireland. Retrieved from https://colettekelleher.ie/wp-content/uploads/ 2019/12/Money-Message-David-Kenny-and-EoinDaly.pdf

Lee, J. W. (2018, February 8). Dail passes bill to stop state issuing licences for fossil fuel exploration. Green News. Retrieved from https://greennews.ie/ government-opposes-bill-stop-state-issuinglicenses-fossil-fuel-exploration

Lijphart, A. (1999). Patterns of democracy: Government forms and performance in thirty six countries. New Haven, CT and London: Yale University Press.

Little, C., \& Torney, D. (2017). The politics of climate change in Ireland: Symposium introduction. Irish Political Studies, 32, 191-198.

Lynch, C., \& Lawlor, D. (2019). L\&RS note: Private Members' Bills (PMBs): Admissibility, government messages and detailed scrutiny (updated note). Dublin: Government of Ireland. Retrieved from https://
data.oireachtas.ie/ie/oireachtas/libraryResearch/ 2019/2019-05-30_I-rs-note-private-members-billspmbs-admissibility-government-messages-anddetailed-scrutiny-updated-note_en.pdf

Mangat, R., Dalby, S., \& Paterson, M. (2018). Divestment discourse: War, justice, morality and money. Environmental Politics, 27, 187-208.

McConnell, D. (2019, November 6). TDs claim in high court that Ceann Comhairle's decision to disallow bill is unconstitutional. Irish Examiner. Retrieved from https://www.irishexaminer.com/news/arid 30962234.html

McCrave, C. (2019, July 5). Decision to halt climate emergency bill described as 'utter hypocrisy' on side of the government. TheJournal.ie. Retrieved from https://www.thejournal.ie/bruton-letter-blockingclimate-emergency-bill-4712252-Jul2019

O'Doherty, C. (2019, July 9). Environmental groups deliver devastating critique of the government's climate action plan. Irish Examiner. Retrieved from https://www.irishexaminer.com/news/arid30935772.html

O'Sullivan, K. (2018, February 7). Bill proposing ban to fossil fuel exploration clears first hurdle in Dáil. The Irish Times. Retrieved from https://www. irishtimes.com/news/environment/bill-proposingban-to-fossil-fuel-exploration-clears-first-hurdle-ind\%C3\%A1il-1.3383861

O’Sullivan, K., \& Horgan-Jones, J. (2019, July 5). Fine Gael accused of 'greenwashing' as climate emergency bill killed off. The Irish Times. Retrieved from https://www.irishtimes.com/news/politics/finegael-accused-of-greenwashing-as-climateemergency-bill-killed-off-1.3947046

People Before Profit. (2019a, May 29). Environmental groups and Green Party come out in support of people before profit's climate emergency bill. People Before Profit. Retrieved from https://www.pbp.ie/ environmental-groups-and-green-party-come-outin-support-of-people-before-profits-climateemergency-bill

People Before Profit. (2019b, November 5). Statement on Dáil motion to unblock opposition bills stalled under undemocratic money message requirement. People Before Profit. Retrieved from https:// www.pbp.ie/statement-on-dail-motion-to-unblockopposition-bills-stalled-under-undemocratic-moneymessage-requirement

Sargent, N. (2018, December 18). Fine Gael opposition leaves climate bill in committee limbo. Green News. Retrieved from https://greennews.ie/finegael-opposition-leaves-bill-committee-limbo

Torney, D. (2017). If at first you don't succeed: The development of climate change legislation in Ireland. Irish Political Studies, 32, 247-267.

Torney, D. (2020). Ireland's policy response to climate change: An historical overview. In D. Robbins, D. Torney, \& P. Brereton (Eds.), Ireland and the climate cri- 
sis (pp. 37-54). London: Palgrave Macmillan.

Torney, D., \& O'Gorman, R. (2019). A laggard in good times and bad? The limited impact of EU membership on Ireland's climate change and environmental policy. Irish Political Studies, 34, 575-594.
Tsebelis, G. (1995). Decision making in political systems veto players in presidentialism, parliamentarism, multicameralism and multipartyism. British Journal of Political Science, 25, 289-325.

\section{About the Authors}
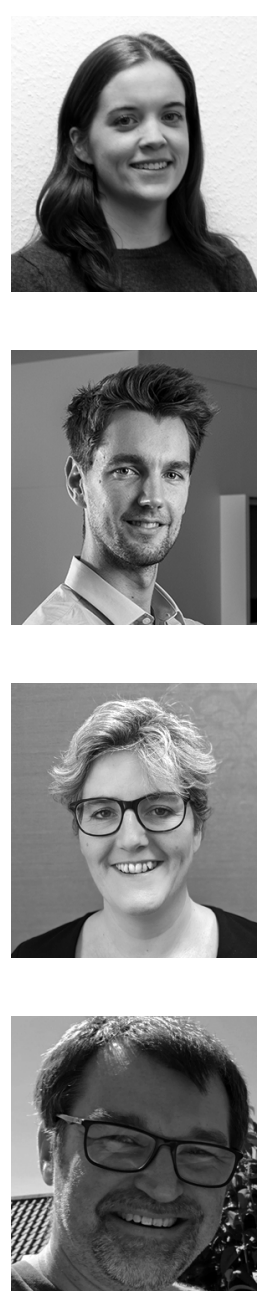

Louise Michelle Fitzgerald is a Postdoctoral Researcher on the ERC SHARECITY project at the Department of Geography, Trinity College Dublin, Ireland. Louise's research is particularly focused on the societal dimensions of sustainability transitions, and how to develop just and inclusive governance approaches.

Paul Tobin is a Senior Lecturer in Politics at the University of Manchester, UK. He specialises in European and environmental public policy. Paul is currently leading a three-year project on European climate governance; the support of the Economic and Social Research Council (ESRC) is gratefully acknowledged, having funded him via grant ES/S014500/1 during his involvement in this article.

Charlotte Burns is Professor of Politics in the Department of Politics and International Relations at the University of Sheffield and Co-Chair of the Brexit and Environment Network. Her work focuses upon EU and UK Environmental Policy and Politics.

Peter Eckersley is a Senior Research Fellow in Public Policy and Management at Nottingham Trent University (Nottingham, UK), a Research Associate at the Leibniz Institute for Research on Society and Space (Erkner, Germany) and an Editor of Local Government Studies. His research focuses on centrallocal government relations, public policy, climate change, sustainability and public accountability. 